Dossiê

\title{
Building a Dialogue Between Feminist, Post- (De)Colonial And Bourdeusian Studies to Analyse the Production And Negotiation of Difference in A World on the Move: The Case of Brazilians in London
}

Angelo Martins $\mathrm{Jr}^{1}$

Abstract: Drawing on research with Brazilian in London, which combined 18-month ethnography in places of leisure with 33 in-depth interviews, this articles builds a theoretical framework, through a dialogue between feminist, post-(de)colonial and Bourdeusian studies, in order to analyse the production and negotiation of difference in a globalised world. The article argues that a dialogue between (black) feminist, post and de-colonial theory, and a more flexible and multi-varied approach of the work of Pierre Bourdieu, analytically developed in migration studies by Abdelmalek Sayad, proves to be useful to analytically address how people are constantly producing and negotiating difference in a 'world on the move'.

Key words: Post-colonial Bourdieu, Brazilians in London, Black feminism, De-colonial studies

1 Department of Sociology of Goldsmiths College, University of London / Centre for Urban and community Research (CUCR/Goldsmiths College) - Londres - Reino Unido - a.martins-junior@gold.ac.uk 


\section{Introduction}

There is only Brazilians here, too many for my taste. It's not being racist, but our race here sucks. They don't know how to behave properly. They just talk about shit all the time. They want to know everything about your life and just think about money and do illegal things. Goianos are the worst. The worst of the Brazilian race here. [Rita, 35-year-old Brazilian woman living in London].

Through the lived experiences and narratives of Brazilian migrants in London, I have developed a 4-year research exploring the intersections between processes of social differentiation and international migration (see MARTINS JR, 2016). From combining an 18-month ethnography in places of leisure with 33 in-depth interviews with Brazilians in London, it was possible to see that the group is diverse, comprised of individuals from different class backgrounds, regions, and genders, which shapes both their decisions to migrate as well as the distinct ways in which they live their lives in London. Moreover, these differences do not disappear when Brazilians arrive in London, but are constantly being re-signified, re-made and negotiated in a new context as a way to value themselves in a context in which the figure of 'the migrant' has been increasingly stigmatised and criminalised (see TYLER, 2013). When talking to Brazilians in London, they were continuously re-inventing, producing and negotiating (essentialised representations of) 'cultural', class, gender, 'race', immigration status and regional differences, which often resulted in processes of social differentiation and racialization that affect how Brazilians relate to each other and to city spaces. My conversation with Rita above, for instance, highlights some of these divisions among the Brazilian population in London.

In order to analytically examine the struggles in which multiple social hierarchies are being produced and negotiated in complex ways in a 'world on the move' (a globalised world), I have drawn on a range of theoretical traditions. Firstly, borrowing from Avtar Brah (1996: 225), I have analysed the concept 'difference' through 'the variety of ways in which specific discourses of difference are constituted, contested, reproduced or re-signified'. In other words, difference is not always a marker of hierarchy and oppression, but is contextually contingent. In this article, I pay attention to the circumstances that enable 'difference' to be organised hierarchically, rather than laterally - in other words, when 'difference' itself 'becomes the modality which domination articulates' (1996: 173), thus, resulting in the production and negotiation of hierarchies. Yet, 
as Brah further argues, in order to understand these processes, we need a conceptual framework that does not privilege either the macro - or the micro-level of analysis, or a specific axis of differentiation, such as class. Rather, we need to theoretically account for how articulating historically embedded discourses and practices inscribe social relations, subject positions and subjectivities through multiple axes of differentiation. Following this (and drawing on my data with Brazilians in London), in the following sections of this article I demonstrate how a dialogue between (black) feminist, post and de-colonial theory (more specifically the de-colonial concept of 'coloniality power'), and a more flexible and multi-varied approach of the work of Pierre Bourdieu, analytically developed in migration studies by Abdelmalek Sayad, can be useful to analytically address how people are constantly producing and negotiating difference in a globalised world.

\section{Post-colonial theories and the Racialization of bodies and spaces through 'cultural' differences}

It's hard to live in Brazil. They don't know how to behave themselves: they talk too loud, spit on the floor, they don't respect queues, push you and don't even say sorry. Everyone takes advantage of each other, uneducated people, without culture and morals! That's why I left there. Here they're civilised. They're polite. You don't see people jumping the queue, throwing rubbish on the floor, gossiping about each other's lives. They respect your space, your opinion, how you dress. Did you see those (English) ladies sat next to us in the pub? Could you hear what they were talking about? No! Because they have culture, manners, education - something that we don't have. [Rachel, 42-year-old Brazilian woman. Extract from the beginning of her interview]

When analysing my data, it was often noticeable how, when reflecting on their lives in London, Brazilians frequently make comparisons between Brazilian and Western European/British 'culture'. It is common to hear people citing Brazil's allegedly inferior/ immoral 'culture' and lack of 'civilization' to explain why they wanted to go to London or why, once arrived, they do not want to go back, as it can be seen with my conversation above with Rachel. Yet, when doing so, Brazilians tend to reproduce and re-signify, in new situations and contexts, racialized representations that inferiorize themselves in comparison to Europeans. These representations are constructed on the basis of a set of homologous 
oppositions embedded in representations constituted as part of the European/ non-European divide constructed during colonisation.

Post- and de-colonial studies assert that the racial/ethnic hierarchy of the European/non-European divide has been continuously re-signified since colonisation, justifying global inequalities by racializing bodies and spaces as physically, intellectually and morally inferior, to non-civilised lifestyles (GROSFOGUEL, 2013; SAID, 1979; GILROY, 1993). This process of racialization has imputed allegedly fundamental characteristics to people, 'writing those character qualities onto their bodies, into their genes and their essential nature' (SPICKARD, 2013: 14), based on their membership of racial/ethnic groups. As Puwar (2004) discusses, in the European process of racialization, non-European bodies were represented as savage and uncivilized and non- European spaces as wildernesses, both in need of taming, while white bodies were associated with spirit and mind. Thus, the process of racialization of groups was interlinked with the creation of racialized spaces.

As Knowles (2003) outlines, there is a spatial dimension of 'race' making. 'Race' and ethnicity become attached, through a number of social mechanis$\mathrm{ms}$, including stories, to physical space or territory. Since colonisation, stories connecting 'race' and spaces have carried a history of imaginary geographies on a global scale, in which spatial and cultural boundaries have been drawn between 'civilization' and various uncivilized, deviant 'others' (SIBLEY, 1995). In this process, space was used to establish a hierarchy, which distinguished civilized Europeans from uncivilized native peoples (LEVINE-RASKY, 2016; SIBLEY, 1995). As Sibley argues, the world colonial map, with civilization in the centre and the grotesque adorning the periphery, illustrated that while there was a 'fascination with non-European cultures...there were both moral and economic arguments for representing these cultures as less than human, a part of nature, or monstrous' (1995: 52).

Nevertheless, justifications to racialize non-European bodies/spaces moved from explanations based on 'religion' (not having a soul) to 'race' (not having the 'right biology') and, contemporarily, to 'ethnicity' (not having the 'right culture') (GROSFOGUEL, 2013: 83-84). The latter, 'ethnicism', imposes stereotypic notions of 'common culture' defining the experience of racialized groups primarily in 'culturalist' terms (BRAH, 1996). This emphasis on culture instead of biology, as Grosfoguel writes, has been legitimized by 'academic approaches that portray high poverty rates among people of colour in terms of their traditional, inadequate, under-developed, and inferior cultural values' (2002: 213; see also SOUZA, 2012). Following this logic, Brazilians often speak in 'culturalist' 
terms, in which 'culture' is conceptualised as an independent factor that determines the fate of those who 'possess' it (BRAH, 1996; GROSFOGUEL, 2002), positioning themselves as being 'body' in comparison to the European ' $m i n d$ '. Thus, the representation of European/British culture tends to acquire a positive value and to be counter-posed against Brazilian culture through a set of homologous oppositions that were present in Brazilian minds even before they migrated. They used the follow words to describe the divide between Brazilians and Western Europeans: rude/polite, emotional/rational, uncivilised/civilised, tradition/modern, exotic/beautiful, macho(sexist)/prince, promiscuous/moral, corrupt/pure, uneducated/cultured, disorganized/organised, gossip (controlled)/individuality (freedom), inequality/equality. As a result, there seems to be a tacit enchantment with Western European culture, which is taken as 'the culture, the universal reference to be followed.

Here, I mark Brazilian (and Western European) 'culture' with speech marks when culture is taken as an essentialised feature that homogenously determines the behaviour of those who share it. Following Brah (1996), I take 'national culture' as a diverse and dynamic process which is in permanent construction. And, Brazil, for instance, is a big and diverse country, with stark regional differences. When doing my interviews, I found many 'Brazils' and many versions of 'its culture' constructed in different regional and classed accounts. However, when I analyse 'the Brazilian culture', in my work, I am analysing an essentialised representation often present in European and Brazilian imaginations.

I am not suggesting, however, that there is no such a thing as cultural differences between Brazilians and Europeans. 'Culture is essentially a process, but this does not mean that we cannot talk about cultural' specificities and artifacts - such as 'customs, traditions and values' (BRAH, 1996: 231). Culture, as noted by Omar Lizardo (2010: 19) dialoguing with Bourdieu (1996), is also a system of action and perception that is acquired in a tacit state through tacit mechanisms along the individual's trajectory. It composes all that marks, 'which is at once hidden and displayed, inscribed on the body, on gesture, postures, ways of carrying (porter) one's body and behaving with one’s body' (SAYAD, 2004: 261). Yet, such cultural specificities do not necessarily constitute social divisions. Neither

2 Such representations, both of Brazilians and Europeans, are also very much classed representations. The Brazilian middle-class uses the same divide between 'body' and 'mind' to distinguish themselves from 'poor immigrant'. They are 'mind' and the 'economic migrant' is 'body'. At the same time, the representation they have of European culture homogenises Europeans as 'mind', ignoring the presence of poor within Europe (Martins Jr, 2017), who have also historically long been associated with the material and the embodied (BOURDIEU, 1984; PORTER, 2003). 
are cultural differences just the outcome of a simple process of differentiation. In fact, cultural difference can be the basis of racializing imperatives when such "difference" is constructed within the interstices of socio-political and economic relations', in which social groups (and their "cultures") 'with differential access to wealth, power and privilege are ranked in relation to one another' (BRAH, 1996: 19) - as it is the case with Brazilians and Western Europeans.

Thus, I draw on post- and de-colonial discussions to understand how Brazilians re-signify and negotiate racialized representations of 'the Brazilian culture' as exotic and uncivilised in comparison to 'Western European culture. Yet, the early work of Bourdieu in Algeria, as well as the work of Sayad with Algerian migrants in France, whom analytically developed Bourdieu's discussions in migration studies, is also helpful to analytically understand how migrants often not only reproduce, but also (contradictorily) negotiate and revolt against essentialised representations of themselves, as well as of Europeans/British people.

\section{Producing and negotiating racialized representations: a post-colonial Bourdieu (?)}

It is hard to be real friends with British people. They are very robotic, programmed. They apologise for everything, but it's not real, it's fake, it's trained, it lacks love, it lacks soul, they are cold people. We [Brazilians] have our problems but we are warm people, honest with our feelings. We go for a Sunday dinner in Brazil, with our family and it is that mess, but we are honest with our feelings, we have life, fire, we fight, we apologise, we hug, we cry, we laugh [Rachel. Extract from her interview, one hour after she made the comments presented in the quote above]

Drawing on my data, it was important to notice how Brazilians were not only often producing and reproducing racialized representations of Brazilian 'culture', but they were also constantly negotiating and reframing both 'Britishness' and 'Brazilianess' in specific contexts. They do so by often contradicting the racialized accounts that they had told me earlier, as it is the case with Rachel above. Similarly to the post-and decolonial studies mentioned previously, the early work of Bourdieu in Algeria as well as the work of Sayad, also problematise how the application, meaning, and function of 'racism' has to be seen as something constructed, contested and tied to determinate contexts and how its use needs to be specified in different times and places. Yet, their work also helps us to analyse the fact that in order to understand how racialized representations of groups are produced, reproduced and negotiated 
we need to take into account the 'physical' characteristics of the body, culture, class, language; and the different weightings these are given and negotiated in various contexts (LOYAL, 2018).

The articles of Steven Loyal (2018) and Julian Go (2018) in this special issue already theoretically highlighted similarities and possible dialogues with the post-colonial discussions with Bourdeusian theory, by demonstrating how Bourdieu's early work in Algeria (1961) provides a number of sociological insights into social relations involving ethnicity and 'race', which were further developed in migration studies by Sayad with Algerians in France. Bourdieu defined colonialism, for instance, as a system of racial domination based on physical and symbolic coercion, in which "the function of racism is none other than to provide a rationalization of the existing state of affairs so as to make it appear to be a lawfully instituted order" (1961: 133). Besides the direct physical coercion, for Bourdieu (1961), the colonial system shaped interactions and behaviours by reproducing a distinct and binary roles for colonizer and colonized through the imposition and adoption of stereotypical representations that defined what French and Algerian/Arab meant to be. Stereotypes of Algerians as uneducated/ uncivilised were constructed in contrast to the educated/civilised Europeans those holding positions of prestige and power - within generalised frameworks that oriented how they interpreted one another's behaviour (LOYAL, 2018). As argued by Bourdieu (BOURDIEU, 1961), the colonial system could only function properly 'if the dominated society is willing to assume the very negative nature or "essence" (the Arab cannot be educated, is improvident, etc.)' (134). In other words, the extreme differences in power influenced the self-perception of the dominated groups came to see themselves through the eyes of the dominant (LOYAL, 2018), compelling the Algerians to "play the role of the Arab-as-seen-by-the-Frenchman" (BOURDIEU, 1961: 161).

Such racial relationship of subordination was, according to Bourdieu (BOURDIEU, 1961), often marked, read and hierarchically expressed through "words and body gestures", as the way of talking, walking, greeting, shaking hands, smile - things that seemed to be the most conventional way of behaving for the colonizer but to the colonised might be "signs of recognition" (GO, 2018). Yet, such process of self-identification and evaluation through they eyes of the dominant, was not a simple one-way process of domination. Discrimination, domination, and widening inequality generated by colonial policy also often resulted in resentment and revolt (BOURDIEU, 1961; LOYAL, 2018). These analytical discussions were in dialogue to the ways in which Sayad (2004) found disempowered migrants shaping and negotiating their self-perception 
in France. Due to necessity and to the dominated position they occupied in the structures of symbolic power relations, Sayad (2004) argued that an immigrant ' (when he [they] is at the bottom of the social hierarchy within the world of immigrant) assumes the stigma which, in the eyes of public opinion, create the immigrant' (286), making them to 'accept (resignedly or under protest, submissively or defiantly, or even provocatively) the dominant definition of his [their] identity' (idem). As a consequence, these migrants often put an effort into their 'self-presentation and representation (the representation others have of him [them], and the representation he [they] wishes to give himself) (SAYAD, 2004: 287'). Such effort is focused essentially on their body, such as 'physical appearance [...], skin colour, hair etc; cultural signs such as accent, manner of speech, clothes, the wearing of a moustache' (idem). As it was the case with the relationship with the coloniser and the colonised in Algeria, stigmatisation and humiliation can not only result in the migrant internalising and adopting the representation of the migrant reproduced by the dominant group, but it can also lead to revolt and subversion (Sayad, 2004). In this sense, what is important here for us is the fact that such 'cultural marks' are not only inscribed on the bodies, but also become part of the struggle over classification, in which dominant and marginalised groups can come to define (and negotiate) themselves and each other through such categorisations, as it is the case with the figure of the migrant.

According to Sayad (2004), the figure of the stigmatised migrant is 'the perfect embodiment of otherness' inside the nation state (SAYAD, 2004). They are part of a different history, (often) coming from a country/continent that occupies a political, economic and culturally dominated position in the world system on the international chessboard' (168). In the struggle against stigmatisation - 'the struggle to define the principles that define the social world in ter$\mathrm{ms}$ of one's interests (material and symbolic)' (idem: 256) - at times the migrant 'revolts against the stigma' ("subversion"), 'at others, the migrant devotes himself to the quest for "assimilation" (286). The latter means trying 'to promote a self-image as close as possible to the (legitimate)' dominant culture (idem: 256). In this sense, "assimilation" 'involve the recognition of the criteria of judgment that base "identity" on a legitimate foundation', while subversion attack 'symbolic power relations, to invert the scale of values that authorises stigmatisation, rather to erase the stigmatised features' (256-7).

Sayad's work resonates with my findings among Brazilians in London, since Brazilians are constantly negotiating racialized and stigmatised representations of Brazilians (as well as migrants) through contradictory strategies of 
'assimilations' ('I am no longer Brazilian'/ 'I am not a migrant') as well as recognition ('I am Brazilian'/ 'I am a migrant') and subversion (valuing being Brazilian and de-valuing Europeans). Brazilians use such strategies of subversion when they face situations in which they try to undermine the stigma against Brazilians or when 'being Brazilian' acquires a positive symbolic meaning. Yet, in the process they tend to re-invert the scale of values that facilitated stigmatisation by giving a negative value to 'Britishness' and a positive value to 'Brazilianess'. As Bourdieu (1991) highlights, symbolic properties, even the most negative, can be used strategically according to the material and symbolic interests of their bearer. Similarly, Brah (1996) argues that racism does not impose 'simple bipolarities of negative and positive, superiority and inferiority', rather it 'simultaneously inhabits spaces of deep ambivalences, admiration, envy and desire' (15). Often, during my fieldwork, and even during the same interview, people used both strategies of recognition and subversion in different moments, navigating such spaces of ambivalences which they narrate through often contradictory accounts - as we could see above with the two extracts from different moments of the same interview with Rachel. Such navigating process, which is constantly negotiated, is possible because they are based on social representations which are both objective and subjective (mental) categories (BOURDIEU, 1991; SAYAD, 2004).

As Sayad (2004) argues, social representations are subjective since they are 'translated into acts of perception and evaluation, cognition and recognition' - a whole series of 'acts in which agents invest their material and symbolic interests, their social prejudice, their presuppositions, their whole social being' (284). Social representations are also objective, due to the fact that 'all external signs/ markers, features and characteristics can become objects of the manipulative symbolic strategies' (285) we use in the struggle over classification to determine the (mental) representations that others have of those properties.

As Bourdieu (1991) notes, struggles over classifications, such as 'racial' and ethnic representations, are struggles over 'the monopoly of power to make people see and believe, to get them to know and recognize, to impose the legitimate definition of the divisions of the social world and, thereby, to make and unmake groups' (221). Thus, these representations become part of the maintenance of social and symbolic order by 'setting up frontiers between "us" and "them", the "normal" and the "deviant"/"pathological", "insiders" and "outsiders" (BOURDIEU, 2014; see also HALL, 1997). However, despite being taken as supposedly obvious and natural 'types', Bourdieu (1991), Sayad (2004) and Post-colonial scholars (see for instance HALL, 1997; ALI, 2005) have shown how they are 
social categories that are highly unstable and always incomplete and that the processes in which they are produced need to be constantly repeated - via images, narratives, discourses and practices.

This instability and open-endedness make room for a series of symbolic strategies in which the subjects try to impose the definition of representation which flatters them the most (SAYAD, 2004; BOURDIEU, 1991). These representations are both objective and subjective: they incorporate the 'racial'/ethnic, classed and gendered cultural markers of difference including language, clothing, religious practice, eating habits - all the material properties, stigmata or emblems linked with the place of origin and its durable associated marks, such as accents, or colour, which have historically been hierarchically classified (ALI, 2005; BOURDIEU, 1991). In other words, on the one hand, they are inscribed in the very being of subjects, in their bodies, habitus and their ways of structuring the social world (as will be further developed later in this article). On the other hand, they are part of the outside world in which one has to operate, where the representations have an emblematic value and function as they are placed under positive and negative values (SAYAD, 2004).

Thus, as Sayad (2004) has argued, the field is open for a whole series of manipulations designed to impose particular representations of oneself and the representation others should have both of the characteristics we agree to regard as distinctive, as well as of those who bear those same differential marks, whether 'racial', classed or gendered. This allows the agents to try to impose the definition or (mental) representation that is in their best social interests by using the properties (external signs, features and characteristics) at their disposal in symbolic manoeuvres aimed at shaping the (mental) representations that others have of those properties. Thus, representation might be understood as something which is not only imposed or ascribed but which is also as a matter of negotiation, connection and imagination - where power can be imposed as well as resisted (HALL, 1997; BRAH, 1996), depending on the context and on the properties/signals that the subject has at their disposal (BOURDIEU, 1991; SAYAD, 2004).

However, the ways in which my respondents navigate strategies of 'assimilation', distancing and subversion when dealing with the stigma against 'Brazilian culture' as well as that against 'the migrant' vary according to the context and to the different markers (class, gender, regional origin and documental status) and resources that they have available to be mobilised in an attempt to value themselves. This brings us to the importance of black feminist and de-colonial discussions on multiple axes of differentiation. 


\section{Intersectionality and coloniality of power}

I am not like these 'illegal' Brazilians who come here to save money and buy a piece of land in Brazil, like the "Goianada" [Goianos, a person from the state of Goías]. Look at the girls how they behave, they are all promiscuous, prostitutes! This is why no one respects Brazilian women here. They get here and the first thing they do is find a stranger to get married just to have their [European] documents. [Priscila, 36-year-old Brazilian woman]

Throughout my work I analyse how Brazilians are constantly negotiating stigmatised representations of the Brazilian 'culture' as well as the migrant by trying to value themselves through the markers of class, region, gender, and documental status, as we can see with Priscila trying to distance herself from 'the bad Brazilian migrant', who is an undocumented migrant (whom she calls 'illegal'), from the state of 'Goías', who migrated to 'save money' (they are 'poor') and are 'prostitutes' (referring to Brazilian women). Post-, de-colonial and bla$\mathrm{ck}$ feminists have shown how process of racialization and social differentiation are also constituted by other social markers, not only by 'race' or 'culture'. In the late 1980's, such scholars published critical texts about gender relations, which sought to think through male domination outside white Western logic (CRENSHAW, 1989; MOHANTY, 1988). The black feminist movement argued for the necessity of understanding the process of gender racialization, as black women experienced a different and more intense kind of oppression from that of white women (DAVIS, 1981; COLLINS, 2000 [1990]).

The concept of intersectionality was borne out of the discussions of black feminists, border theorists and subaltern studies. It refers to the idea that cultural patterns of oppression are bound together and shaped through intersecting systems of social division, such as class, gender, and ethnicity (COLLINS, 2000; CRENSHAW 1989; ANTHIAS AND YUVAL-DAVIS, 1992). Following the work of Brah (1996), Floya Anthias and Nira Yuval-Davis (1992) and Nirmal Puwar (2004), I argue that the concept of intersectionality should not be understood to describe independent structures with links between them, but rather, should be used to analyse how linkages are inbuilt from the start. Following this, the concept of intersectionality has become fundamental to contemporary discussions which seek to provide analytical tools to comprehend the articulation of multiple differences and inequalities in specific contexts. The concept has been applied to the study of many other social relationships of power beyond gender and 'race', including sexuality, disability, nation, state and class (Brah and 
Phoenix, 2004; Anthias and Yuval-Davis, 1992). As a consequence, it has influenced not only feminist but also post(de)-colonial debates.

Post - and de-colonial studies (MCCLINTOCK, 1995; COLLINS, 2004), for instance, drew attention to the need to articulate gender not only with sexuality, 'race' and class, but also with religion and nationality, stating that 'race' and colonialism have equally been central to the formation of (imperial) public masculinity and femininity. Within a similar vein, Latin American de-colonial scholars conceptualize the present world system as a historical-structural heterogeneous totality with a specific power matrix that is referred to as a 'colonial power matrix' (QUIJANO, 2000). This 'matrix of power' was constituted during European colonisation, dividing the world population between Europeans (conceptualised in terms of mind/reason) and de-valued non-European (conceptualised in terms of body/nature). Yet, this division has been continuously re-produced and re-signified since colonisation, racializing bodies and spaces as morally and intellectually inferior through the intersections of 'race', ethnicity, gender, class, sexuality, spirituality, and epistemology (GROSFOGUEL, 2002).

The theorizing of intersectionality and the coloniality of power provides me with a framework which encompasses different axes of social differentiation and racialization, emphasizing that 'different dimensions of social life cannot be separated out into pure and discrete strands' (BRAH; PHOENIX, 2004: 76; SEE ALSO ANTHIAS; YUVAL-DAVIS, 1992). In my work, I draw on these studies to discuss how gender plays an important role, intersecting with 'culture', when Brazilians reproduce and negotiate the racialized representation of 'Brazilians' as non-modern bodies. Moreover, I also draw on discussions of intersectionality throughout my work to discuss how Brazilians in London also constantly produce and navigate social differentiation among themselves using intersected axes of differentiation - class, gender, immigration status, region and 'race'. Within these negotiations, Brazilians often display how 'classes are always gendered and racialized and gender is always classed and racialized and so on' (ANTHIAS, 2012: 106). Intersectionality allows me to analyse how Brazilians negotiate divisions among the population not only by using social markers that compound each other, but also by using some social markers to compensate for or 'cancel out' others (BRAH, 1996; PUWAR, 2004). I discuss, for instance, how region and 'culture' can be used by the Brazilian working class to compensate for their stigmatised class positioning in London. It is important to highlight that in examining the dynamic character of these negotiations, I treat these social markers and their boundaries as social categories that 'are not fixed': their 'social and political meanings can vary in different historical contexts as well as 
being continually challenged and restructured both individually and socially' (YUVAL-DAVIS, 2006: 201; SEE ALSO ANTHIAS; YUVAL-DAVIS, 1992). In this sense, following Anthias (2012), I frame intersectionality 'as a process', rather than as 'an interplay in peoples' group identities of class, gender, ethnicity, racialization and so on' (107). In so doing, I consider how these different intersected markers produce 'contradictory locations' in which actors are placed 'as subordinate in some times and places and more dominant in others' (idem).

Nevertheless, there are two theoretical and analytical considerations regarding intersectionality that I take into account. Firstly, as Beverley Skeggs and Helen Wood (2011) have argued, it is difficult and complex to think through the systems or logics that produce how we live these social markers, all together, in everyday experience. Hence, for the purpose of my work, I initially focused my analysis on the intersection of 'culture', class and region, in how Brazilians re-signify difference in London. Yet, in many circumstances, during my research, these three markers were intersected by gender, 'race' and documented status in the production of divisions among Brazilians themselves and in between Brazilians and other national/ethnic groups. Secondly, foundational work on intersectionality uses varied theoretical approaches, such as Foucault, Gramsci and psychosocial analyses (CRENSHAW, 1991; MCCLINTOCK, 1995; BRAH, 1996) to understand the articulation of power, domination and resistance through different axes of differentiation. My work dialogues with these studies, especially with the work of Brah (1996) and with Latin American de-colonial literature. However, I argue that a dialogue with the work of Pierre Bourdieu, which takes into account social forces such as the state, class domination and the production of power relations through social practice, helps me to empirically address how differences are (re)produced on a daily basis in a world on the move.

According to Bourdieu, 'the question with which all sociology ought to begin' is 'that of the existence ... and mode of existence of collectives' (BOURDIEU, 1991: 250). For Bourdieu, the construction of the modes of social existence of collectivities occurs with social and symbolic boundaries being simultaneously constructed through 'social practices, rather than theoretical conjecture' (WEININGER, 2005: 85). I argue that Bourdieu's science of practice, and the 'correlative critique of domination in its manifold manifestations', based on 'the historicization of the agent (habitus and capital) and the world (social space and fields)' (WACQUANT, 2016: 64-65) allows us to empirically address how power and domination are produced through different axes of differentiation. Even though Bourdieu's early work in France tends to privilege class in the process of 'social grouping', I will now discuss how my research draws on a revised, 
more flexible and multi-varied Bourdieusian approach, which also takes into account the primary role of other markers - gender, 'race' and ethnicity - not only in individuals practices (actions and attitudes), but also in the constitution of collectivities.

\section{Framing class as embodied lifestyle: the legitimate culture}

I used to attend many Brazilian places. I saw all of this being born [Brazilian places of leisure opening in London], but I also saw these places being attended by these other Brazilians, bringing this funk ostentação and sertanejo. The lyrics are ridiculous, there is no education or culture. It's all about buying goods, superficiality of consumerism, emptiness, lack of morality. It's too low-brow, encouraging promiscuity. [Maria, 54-year-old Brazilian woman]

Brazilians in London often speak of class differences resulting in divisions among the population. Yet, in a context in which migration fractures the boundaries of class by producing situations of occupational downgrade, for instance, the markers used by the middle-class to reinvigorate class boundaries are constantly negotiated and re-signified according to their position in social space. Within this negotiation, level of education, morality and taste, as we could see with Maria, are the main markers through which such divisions are produced by the middle-class. This brings the analytical importance of Bourdieu's class definition to my work.

Bourdieu frames class as a combination of economic and social cultural factors (BOURDIEU, 1984), which link one's class situation to a particular lifestyle. This lifestyle constructs objective ties of solidarity, on the one hand, and prejudice on the other, as it is part of a symbolic system that ranks valued and non-valued lifestyles. This allows me to understand the complexity of migration beyond the idea of solidarity and homogenous 'ethnic community', since differences of class (lifestyles) affect the everyday experience of migrants in respect to the ways in which they relate to each other and to the city.

For Bourdieu (1987a), social groupings (such as social classes) do not exist anteriorly; what exists is a social space, 'a space of differences' (3), in which classes exist in a type of virtual state, not as a given but as something to be constructed (see also BOURDIEU, 1991). Social space is organized by cross-cutting principles of differentiation and capital (BOURDIEU, 1991). Capital, for Bourdieu (1986), is any 'resource effective in a given social arena that enables one to appropriate the specific profits arising out of participation and contest in it' 
(WACQUANT, 2008: 268). As summed by Wacquant (2008), there are four dimensions of capital: 'economic (material and financial assets), cultural (scarce symbolic goods, skills, and titles) and social (resources accrued by virtue of membership in a group)' (268). These three resources become socially effective, and their ownership is legitimized through the mediation of symbolic capital, the fourth dimension (BOURDIEU, 1984). The position of an agent in social space is, then, relationally defined by the volume (quantity), composition (type) and trajectory (the change or stability an agent experienced over time with the volume and composition of their capital) of capital (BOURDIEU, 1987a; WEININGER, 2005; WACQUANT, 2008). The latter (trajectory), differently position the agents in the social space within class fractions (BOURDIEU, 1984).

The position of an agent in social space has, for Bourdieu (1987a), an indirect causal link with the practices of an agent, which is structured by their habitus. Habitus is a set of internalized pre-reflexive dispositions that are acquired through lasting exposure to particular social conditions and conditionings (BOURDIEU, 1990a). These conditions and conditioning, which the agents are exposed to, are generated by the economic wealth (economic capital) and accumulated culture (cultural capital), which differentiate the spaces to be occupied by the agents. Habitus, however, also has a continuous dimension, being a principle of both social continuity ('it stores social forces into the individual organism and transports them across time and space') and discontinuity ('it can be modified through the acquisition of new dispositions') (WACQUANT, 2008: 268). In other words, habitus captures the permanent internalisation of the social order in the human body at the same time that it recognises the agent's practice - their 'capacity for invention and improvisation' (BOURDIEU, 1990a: 13).

Thus, the incorporation of habitus or cultural dispositions - which is related to the position of the agents in social spaces - results in specific aesthetic sensibilities that orients the agents' everyday choices and lifestyles (BOURDIEU, 1984). Tastes in clothing, music, art, food and sport, as well as trivial everyday behaviours inscribed on the body - such as posture and accent -, work as vehicles through which agents symbolize their social similarity and differences with/from one another (BOURDIEU, 1984; WEININGER, 2005). As a consequence, cultural practices might have unconscious classificatory effects that shape social positions by defining (social) class boundaries through struggles over classification. As Weininger (2005: 98) notes, these are struggles to impose the superiority of the dominant group's worldview and lifestyle as hegemonic, valued or 'the norm'. They are developed within 'fields' (BOURDIEU; WACQUANT, 1992: 16), specific arenas in which 'networks of social relations are 
structured around competition over various stakes, such as academic, artistic, and literary prestige' (LAMONT; MOLNÁR, 2002: 173).

In his classic study Distinction (1984), Bourdieu shows how the logic of class struggle is extended to the field of taste and lifestyle, in which symbolic classifications become key to the reproduction of class privileges. He argues that dominant groups generally succeed in legitimizing their own culture and ways (lifestyles/tastes) as superior to those of lower classes. The 'lower classes' or the working-class are constructed as the antithesis of dominant middle- and upper-classes through oppositions such as distinguished/vulgar, aesthetic/practical, pure/impure, quality/quantity, and manners/matter (BOURDIEU, 1984: 245; LAMONT; MOLNÁR, 2002). In such binary constructions, aesthetics are translated into morality, since those positioned as lacking 'taste' are also positioned as morally lacking (BOURDIEU, 1984; LAWLER, 2005). Thus, taste/lifestyle and morality work as important markers in constructing objective ties of solidarity, on the one hand, and prejudice on the other.

Therefore, as Weininger (2005) argues, within the struggles between classes and between class fractions over the power inside a field, there is an important 'symbolic component' (136). When imposing a specific meaning as legitimate while concealing the power relations that are the basis of its force (BOURDIEU; PASSERON, 1990), the dominant group exercises symbolic violence, which helps in reproducing social inequalities. They use 'their legitimate culture to mark cultural distance and proximity, to monopolize privileges, and to exclude and recruit new occupants to high status positions' (LAMONT; MOLNÁR, 2002: 172), denying the structural power relations, which produce the divisions (through the differential access to cultural and economic capital) in social space. It is through these constant and reciprocal acts of social classification that social collectivities are continuously produced. As Weininger (2005) asserts, analysing the work of Bourdieu (1984; 1990b), 'bounded social groups are the result of practices that seek to symbolically delimit 'regions' of social space' (99). Thus, the symbolic is a 'separative power' which draws 'discrete units out of indivisible continuities, difference out of the undifferentiated' (BOURDIEU, 1984: 479). In other words, any social collectivity is 'the result of the combined symbolic acts of self-classification and classification by others that are applied to its members' and also, as a consequence, to 'those who are excluded' (WEININGER, 2005: 99).

Nevertheless, the composition of the legitimate culture is permanently being played out within the field, as it is the object of a perpetual struggle (WEININGER, 2005). This allows Bourdieu to state that the boundaries between social 
classes are 'flames whose edges are in constant movement' (BOURDIEU, 1987a: 13). As the boundaries constructed through taste and lifestyle arise from practices that are thematically oriented to different ends (that is, to food, art, fashion), these boundaries are 'necessarily indeterminate and fuzzy', existing only 'in the flux of on-going practices' (WEININGER, 2005: 101). Thus, they are porous and not permanent boundaries, which are open for negotiation.

Yet, even though the boundaries are open for negotiation, their narratives are also a product of a set of relations between socially determined positions within a field, and not only a particular relationship to be materialised at a given place and time (SAYAD, 2004). As Puwar (2004) highlights in her engagement with Bourdieu, practice is not simply the result of agents' conscious and deliberate intentions; 'it is part of a process of improvisation, which in turn is structured by cultural orientations, personal trajectories and the ability to play the game of social interactions' (125). In this sense, Bourdieu's discussion of practices, and their constitutive elements, such as capital, field and habitus, play an important role, I argue, in understanding how the Brazilian middle-class re-make class boundaries in London. In my research, I dialogue with Angela Torresan's (2012) work on Brazilians in Portugal, which draws on the Bourdeusian work of Maureen O'Dougherty (2002) on class in Brazil. As Torresan (2012) has argued, when defining Brazilian middle-class boundaries, despite occupation and income being important, there were other attributes that go beyond position in the job market. Middle-classness in Brazil:

involved having a good education that would lead to a stable job with a salary sufficient to acquire a car, save for a house (and eventually buy one), travel, and purchase clothes, and other domestic goods. It was also important to partake in casual and frequent entertainment that would provide some cultural capital and a sense of 'educated' taste with which people could distinguish their situation within the flexible boundaries of the middle class. (TORRESAN, 2012: 115)

Moving the definition of class beyond economic income and occupation helps us to understand how the Brazilian middle-class in London are be able to play cultural (and moral) markers, in order to re-construct class boundaries between them and 'the other Brazilian migrants', those considered to be from the 'lower-classes'. Cultural capital and a sense of educated taste, I argue in my work, become especially important for people's subjective experience of their social location within a context in which migration resulted, for many middle-class Brazilians, in a situation of new class exposure as well as economic/occupational 
downgrade. As highlighted by (REAY, 1997), Bourdieu's concept of habitus (and the interaction within the field, I would add) enables an analysis of social class as complex sociological and psychological processes that encompass far more than materiality and social location, since habitus also takes 'a power of adaptation' (227). In this sense, I bring to Bourdieu's theoretical innovations an empirical analysis of how such adaptation is more evident in a transnational context, in which the Brazilian middle class often need to rely on their cultural capital in order to try to re-establish class boundaries after going through a process of economic downgrade. This power of adaptation, however, is multidimensional, since the construction of habitus and, by consequence, practice and social differentiation, is not only affected by class, as I discuss below.

\section{Intersected fragmented habitus and multiple social differentiation}

Critical literature has identified many difficulties with the understanding of the concept of habitus in Distinction (see BENNETT et al., 2009), which contrasts with Bourdieu's later work in which habitus is defined in open, loose and flexible terms (BOURDIEU, 1990a). As Bennett et al (2009) state, in Distinction, Bourdieu insists on the 'necessary unity of the habitus, anchoring that unity in the conditions of existence, which supply any particular habitus with its determining ground' (25). This would deny the autonomous force of cultural training related to 'gender, ethnicity and religion, and provides small scale for the capacity of trans-national cultural flows to dismantle habitus that are defined in terms of their relations to classes within a purely national conception of the social' (27).

As I am not only analysing class in a context of transnational migration, in which class boundaries are re-made and negotiated in a new context, but also how other social marks intersect with class in producing divisions among the Brazilians in London, I advance Bourdieu's work in Distinction by drawing upon a more flexible Bourdesian perspective. In this perspective, habitus is framed with a level of plasticity that is derived from its intrinsic multi-dimensional and intersectional character, as purposed by feminists and other scholars (SILVA, 2016; PUWAR, 2004; REAY, 1997; SKEGGS, 1997; WACQUANT, 2016). In Distinction, the factors deriving from location in the social space are identified as 'primary', and the demographic characteristics (including gender, age, region and ethnicity) are designated as 'secondary' factors (BOURDIEU, 1984). As Weininger (2005) highlights, in his later work Bourdieu abandoned the assumption that the 'life conditions' associated with a location in social space are the 
fundamental determinants of habitus, also giving an independent role in structuring practice (in a 'multivariate'/intersected logic) to what he had previously called secondary factors, such as gender.

Whatever their position in social space, women have in common the fact that they are separated from men by a negative symbolic coefficient which, like skin color for blacks, or any other sign of membership in a stigmatized group, negatively affects everything that they are and do, and which is the source of a systematic set of homologous differences: despite the vast distance between them, there is something in common between a woman managing director... and the woman production line worker. (BOURDIEU, 2001: 93)

Thus, taking habitus in an intersected or multi-varied logic, not only reformulates the logic of practice beyond class, but it also results in a revision of 'the existence and mode of existence of collectives', since 'social class, as a symbolic principle of vision and division' has to compete with 'other principles (including gender) in the classificatory struggle through which collectivities are constituted' (WEININGER, 2005: 112-13). This is the approach that feminists and other scholars have been theoretically developing and empirically applying. With a revised and more flexible Bourdeusian theory, they have shown how habitus can be used to uncover how class, 'race' and gender are embodied, played out in individuals' actions and attitudes, as well as in a whole range of bodily gestures (REAY, 1997; PUWAR, 2004; SKEGGS, 1997). Structures of class, 'race', and gender shape the continuous construction of the 'bodily habitus' (WACQUANT, 2004). As a consequence, scholars have focused on how a gendered/ racialized/ classed habitus is used to understand the ways in which the socially advantaged and disadvantaged perform attitudes - ingrained in their habitus- of cultural superiority and inferiority in daily interactions (REAY, 1997). Such a playing out is also possible because the habitus is not only multi-varied, but also fragmented.

Elizabeth Silva (2016), for instance, emphasises the fragmented aspect of habitus, in which 'the habitus incorporates differences and is transformed as the person relates to various fields' simultaneously and over time (170). She argues that 'to capture the complex relationalities of the contemporary individual' - often engaged in unconnected multiple relational matrices - a notion of fragmented habitus is more adequate (178). In my work, I draw on the intersected and fragmented constitution of habitus resulting in an intersected and flexible approach to practice and to the formation of social collectivities. It allows me to, on one hand, discuss how the intersection of (an essentialised notion of) 
'culture' with gender, class with gender, and region with class (and 'race' and gender) are used in the construction of hierarchies among Brazilians in London, based on valued ('moral') and dis-valued ('immoral') lifestyles/taste. On the other hand, it also allows me to verify how, when dealing with classed, gendered, regional or 'cultural' stigmatised representation, Brazilians in London play with their multiple relational matrices as a means of managing the stigma and its symbolic violence. Yet, such construction of symbolic boundaries also takes the form of objectified classification with the state production of legal categories.

\section{Institutionalising categories and divisions}

these illegals who come from all parts of the world wanting to take advantage of the country. These people don't come with good intentions. They come to get the money, the benefits. There are a lot of Brazilians here who are tricking the system, so the government needs to get these guys and send them out, because they are tricking the system and destroying these countries [Adriano, 44-year-old Brazilian man]

Documental status is also an important marker in producing divisions and social differentiations among Brazilians in London. This can be seen above in the quote with Adriano, when referring to the undocumented migrant as 'the illegal'. As a consequence, the state and social institutions also play an important role in the production of difference in a world on the move. As argued by Weininger (2005), Bourdieu's theory shows how the fluctuating symbolic boundaries, generated through the play of consumption practices (lifestyle), discussed above, might progressively constitute classifications 'through processes of discursive identification and collective mobilization' that codify the collectivities, by making clear cuts, establishing firm frontiers (151). Such constitution of codified frontiers occurs as soon as any collectivity - and the boundary that separates it from other(s) - assents to the level of discourse. As Bourdieu highlights, 'any predicative statement with "the working class" as its subject conceals an existential statement (there is a working class)' (BOURDIEU, 1991: 250). Thus, here we can see how differences existing in the 'practical state' become transformed into objectified 'frontiers' through the linguistic designation of the collective, the name (social label and/or social representation) (BOURDIEU, 1984: 480). The linguistic designation of a category carries feelings of 'affinity or incompatibility engendered by similarities or differences of lifestyle - a relatively 'serial' state of existence' (WEININGER, 2005: 103). Thus, as Weininger 
(2005) points out, the verbal designation of the collectivity ('I am middle-class') 'enables an explicit recognition of the membership status of oneself and others' (103). Yet, social institutions may act beyond the elementary codification that discourses produce, as they have the power to instate and regulate constitutive boundaries characterized by a higher degree of solidity and permanence. This is the case with the educational system, which Bourdieu and Passeron (1990) analyse, as it has the power to issue credentials and certificates. Social categories such as 'skilled manual workers', for instance, are constrained by the educational system's authority to award credentials and to differentiate between types of credentials ('technical certificates' or 'higher degrees').

Yet, the frontiers demarcating collectivities from one another take their highest level of objectification when they are inscribed into law, produced by the state (BOURDIEU, 2014). For Bourdieu (2014), the state, as well as the judiciary, have the power to create social divisions and to reproduce ethno-national 'social identities' Through its dominant discourse, categorizations and judgments, the state divides the population between citizens and non-citizens, nationals and non-nationals, economic migrants and asylum seekers (LOYAL, 2014; BOURDIEU, 2014). Nevertheless, as Villegas (2004) writes, such a process is made alongside cognitive schemas and classifications, which express the power to impose a legitimate vision of the social world, in other words, 'the power to (re)make reality by establishing, preserving, or altering the binary categories through which agents comprehend and construct that world - as legal/illegal, just/false, moral/immoral, state/individual, citizen/alien etc' (VILLEGAS, 2004: 60). Thus, far from being only legal categories, these categories are part of a symbolic system, which imbues them with (moral) values and functions based on representations (signs and objects) that are both subjective (mental) and objective (BOURDIEU, 2014).

Within this system, the law consecrates the established order by consecrating the vision of that order which is held by the State, 'being centrally involved in the (re)production of symbolic domination and symbolic violence' (LOYAL, 2014: 3). Thus, the law helps to reproduce arbitrary relations of power, which are masked by the naturalized process of naming and categorizing (BOURDIEU, 1987B; LOYAL, 2014). However, following Bourdieu (1987b), the law, as well as the state, is a social field - a set of objective and historical relations between positions of social actors and institutions who struggle over the appropriation of symbolic power. In other words, the state is a social space organized around the conversion of direct conflict and struggle between parties, professionals and groups (VILLEGAS, 2004). This approach opens a space for discussing the 
blurriness within the state itself and its institutions and categories - like the ones produced by immigration laws, which always needs to be de-naturalised and framed within specific contextual power struggles. It is by drawing on this discussion that I am able to analyse, firstly, the blurred institutionalised production of the 'legal' and 'illegal' migrant and secondly, the material and symbolic consequences of the production of this institutionalised divide on how Brazilians live and structure their lives in London. Finally, as these legal categories are also representations based on cognitive schemas and classifications, I also analyse how Brazilians negotiate the stigmatised representation of the migrant (particularly the so called 'illegal') through other axes of differentiation, such as class. Therefore, another important Bourdieusian theoretical frame for my work is how these symbolic and institutionalised processes of classification produce - and are produced by - dynamic representations, which are both objective and subjective, being open for negotiation.

\section{Conclusion}

This article has argued that a dialogue between (black) feminist, post and de-colonial theory (more specifically the de-colonial concept of 'coloniality power') and a flexible and multi-varied Bourdiesian approach is useful to empirically analyse how migrants live and negotiate their lives, and the ways in which relate to each other, in a globalised world. By building such a dialogue, I argue, allows us to analyse the ways in which differences are rearticulated in the everyday making of the global world, and how these differences, rooted in the colonial and postcolonial history of the global world, become reconstituted in new processes of social-differentiation and racialization. In the case with my research with Brazilians in London, more specifically, combining these theoretical discussions allowed me analytically address how it is through the production and negotiation of 'cultural', classed, and regional differences - which are shaped in important ways by gender, 'race', immigration status and colonial legacies - that Brazilians try to values themselves against stigmatised representation of the migrant - asserting affinities with, and repudiations of, particular bodies in London.

\section{References}

ALI, S. Uses of the exotic: Body, narrative, mixedness. In: ALEXANDER, C.; KNOWLES, C. (orgs) Making Race Matter: Bodies Space \& Identity. Basingstoke, Palgrave Macmillan, 2005, pp. 153-171. 
ANTHIAS, F.; YUVAL-DAVIS, N. Racialized boundaries: race, nation, gender, colour and class and anti-racist struggle. London, Routledge, 1992.

ANTHIAS, F. Transnational mobilities, migration research and intersectionality', Nordic Journal of Migration Research, v. 2, n. 2, 2012, pp. 102-10.

BENNETT, T.; SAVAGE, M.; SILVA, E.; WARDE, A.; GAYO-CAL, M.; WRIGHT, D. Culture, Class, Distinction. London, Routledge, 2009.

BOURDIEU, P. On the State: Lectures at the College de France 1989-1992. Cambridge, Polity Press, 2014.

. Masculine Domination. Trans. Richard Nice. Stanford, CA, Stanford University Press, 2001.

The State Nobility: Elite Schools in the Field of Power. Cambridge, Polity Press, 1996.

. Language and Symbolic Power. Cambridge, Polity Press, 1991.

In Other Words: Essays Towards a Reflexive Sociology. Cambridge, Polity, 1990a. Logic of Practice. Oxford, Polity, 199ob.

What Makes a Social Class? On the Theoretical and Practical Existence of Groups. Berkeley Journal of Sociology. v.32, 1987a, pp. 1-17.

The force of law: towards a sociology of the juridical field. Hastings Law Journal. v. 38, n. 5, 1987b, pp. 814-853.

Distinction: A social critique of the judgement of taste. Cambridge, MA, Harvard University Press, 1984.

The Algerians, Boston. MA, Beacon Press, 1961.

BOURDIEU, P.; PASSERON, J. Reproduction in Education, Society and Culture. London, Sage, 1990.

.; WACQUANT, L. An Invitation to Reflexive Sociology. Chicago, University of Chicago Press, 1992.

BRAH, A. Cartographies of diaspora. London, Routledge, 1996.

BRAH, A.; PHOENIX, A. Ain't I a Woman? Revisiting Intersectionality. Journal of International Women Studies. v. 5, n. 3, 2004, pp. 75-86.

COLLINS, P. Black sexual politics: African Americans, gender, and the new racism. New York, Routledge, 2004.

Black Feminist Thought. 2nd ed. New York, Routledge, 2000 (1990).

CRENSHAW, K. Demarginalizing the Intersection of Race and Sex: A Black Feminist Critique of Antidiscrimination Doctrine, Feminist Theory, and Antiracist Politics. University of Chicago Legal Forum. v. 139, 1989, pp. 139-168.

DAVIS, A. Women, race and class. New York, Random house, 1981.

GILROY, P. The Black Atlantic: Modernity and Double Consciousness. London, Verso, 1993. 
GROSFOGUEL, R. The Structure of Knowledge in Westernized Universities: Epistemic

Racism/Sexism and the Four Genocides/Epistemicides of the Long 16th Century.

Human Architecture: Journal of the Sociology of Self-Knowledge. v. 11, n. 1, 2013, pp. 73- 90.

. Colonial Difference, Geopolitics of Knowledge and Global Coloniality in the

Modern/Colonial Capitalist World-System. Review. v. 25, n. 3, 2002, pp. 203-24.

HALL, S. Representation: cultural representations and signifying practices. London, Sage, 1997.

KNOWLES, C. Race and Social Analysis. London, Sage, 2003.

LAMONT, M.; MOLNÁR, V. The Study of Boundaries Across the Social Sciences. Annual Review of Sociology. v. 28, 2002, pp. 167-95.

LAWLER, S. Disgusted subjects: the making of middle-class identities. The Sociological Review. v. 3, n. 3, 2005, pp. 429-446.

LEVINE-RASKY, C. Whiteness Fractured. New York, Routledge, 2016.

LIZARDO, O. Can cultural capital theory be reconsidered in the light of world polity institutionalism? Evidence from Spain. Poetics. v. 33, 2005, pp. 81-110.

LOYAL, S. From the Sanctity of the Family to State Sovereignty: The Irish Supreme Courts Changing Role in Maintaining National Sovereignty. Critical Sociology, 2014, pp. 1-18.

MCCLINTOCK, A. Imperial Leather. London, Routledge, 1995.

MARTINS JR, A. The production and negotiation of difference in a world on the move: Brazilian migration to London. Doctoral thesis, Goldsmiths College, University of London, 2016.

MOHANTY, C. Under Western Eyes: Feminist Scholarship and Colonial Discourses. Feminist Review, v.30, 1988, pp. 60-88.

O'DOUGHERTY, M. Consumption Intensified: The Politics of Middle-Class Daily Life in Brazil. Durham and London, Duke University Press, 2002.

PUWAR, N. Space Invaders: race, gender and bodies out of place. London, Berg, 2004. QUIJANO, A. Coloniality of Power, Ethnocentrism, and Latin America. Nepantla. v.1, n. 3, 2000, pp. 533-80.

REAY, D. Feminist theory, habitus and social class: Disrupting notions of classlessness.

Women's Studies International Forum. v.20, n. 2, 1997, pp. 225-233.

SAID, E. Orientalism. New York, Pantheon Books, 1978.

SAYAD, A. The Suffering of the Immigrant. Cambridge, Polity, 2004.

SIBLEY, D. Geographies of Exclusion: Society and Difference in the West. London and New York, Routledge, 1995

SILVA, E. Unity and fragmentation of the habitus. The Sociological Review. v. 64, 2016, pp. $166-183$. 
SKEGGS, B.; WOOD, H. Introduction: real class. In: WOOD, H.; SKEGGS, B. (eds.)

Reality Television and Class. London, BFI/Palgrave, 2011, pp. 1 -32.

SKEGGS, B. Formations of Class and Gender: Becoming Respectable. London: Sage, 1997.

SOUZA, J. A dimensão simbólica do capitalismo moderno: para uma teoria crítica da modernização. Revista Estudos Políticos. v.5, 2012, pp. 41-59.

SPICKARD, P. Multiple Identities: Migrants, Ethnicity, and Membership, Bloomington, Indiana University Press, 2013.

TORRESAN, A. A middle class besieged: Brazilians' motives to migrate. The Journal of Latin American and Caribbean Anthropology. v.17, n. 1, 2012, pp. 110-30.

TYLER, I. Revolting Subjects: Social Abjection and Resistance in Neoliberal Britain. Zed Books, 2013.

VILLEGAS, M. On Pierre Bourdieu's legal thought. Droit et Société, v. 56/57, 2004, pp. 57-71.

WACQUANT, L. A concise genealogy and anatomy of habitus. The Sociological Review. v.64, 2016, pp. 64-72.

. Pierre Bourdieu. In STONE, Rob. (org.), Key Sociological Thinkers (2nd edition). Bansingstoke, Palgrave Macmillan, 2008, pp. 261-77.

Body and Soul: Ethnographic Notebooks of An Apprentice-Boxer. New York, Oxford University Press, 2004.

WEININGER, E. B. Pierre Bourdieu on Social Class and Symbolic Violence. In: WRIGHT, E. O. (org.), Approaches to Class Analysis. Cambridge, Cambridge University Press, 2005, pp. 116-65.

YUVAL-DAVIS, N. Intersectionality and Feminist Politics. European Journal of Women's Studies. v. 13, n. 3, 2006, pp. 193-209.

Recebido em 20/12/2017

Aprovado em 19/02/2018

\section{Como citar este artigo:}

MARTINS Jr., Angelo. Building a dialogue between feminist, post-(de)colonial and bourdeusian studies to analyse the production and negotiation of difference in a world on the move: the case of brazilians in London. Contemporânea - Revista de Sociologia da UFSCar, v. 8, n. 1, jan.- jun. 2018, pp. 33-57. 